\title{
AN INTROSPECTIVE APPROACH TO WOMEN'S INTERCULTURAL FIELDWORK. FEMALE RESEARCHER'S NARRATIONS BASED ON THEIR INTERCULTURAL EXPERIENCES FROM THE FIELD
}

Recenzja książki autorstwa Urszuli Markowskiej-Manisty i Justyny Pilarskiej An Introspective Approach to Women`s Intercultural Fieldwork. Female researcher`s narrations based on their intercultural experiences from the field. Warszawa: Wydawnictwo Akademii Pedagogiki Specjalnej, ss. 188.

Książka „An Introspective Approach to Women`s Intercultural Fieldwork” Female researcher`s narrations based on their intercultural experiences from the field" pod redakcja Urszuli Markowskiej-Manisty i Justyny Pilarskiej jest niezwykle ważną publikacją o charakterze pedagogicznym i skłania do refleksji na temat pozycji kobiet $\mathrm{w}$ badaniach terenowych oraz specyfiki ich pracy $\mathrm{w}$ tym zakresie. Dzięki zbudowaniu swojej pracy na sześciu niezależnych rozdziałach opisujacych zmagania kobiet na polu badawczym autorki dają nam możliwość poznania tematu z sześciu różnych perspektyw. Kobiety - naukowcy różniące się pod względem wieku, wykształcenia, doświadczenia w pracy badawczej, a także miejsca prowadzenia badań (bliskie i odległe zakątki świata, odmienne geograficznie i kulturowo), przedstawiaja nam czytelnikom obraz trudności zarówno zewnętrznych jak i wewnętrznych, z którymi musiały się zmagać podczas przeprowadzania badań. Dziela się jednocześnie spostrzeżeniami i doświadczeniami zebranymi podczas pracy terenowej, którego nigdy by nie zdobyły pracując za biurkiem. W każdym z artykułów przenosimy się w inną rzeczywistość, poznajemy specyfikę badanej kultury, ale także „widzimy” zmęczenie fizyczne autorek oraz ich wątpliwości natury psychicznej, które często brały górę nad pasja i podejściem akademickim pojawiające się w sytuacji, gdy założenia badawcze konfrontowały się z rzeczywistością. Sa to narracje pisane z kobiecego punktu widzenia, opartego na intuicji, intelekcie i uczuciach.

Anna Odrowąz-Coates w swojej pracy „An ethnographic study about women The female researcher's experience" zajmuje się wybranymi kwestiami związanymi z wyzwaniami prowadzenia badań w odmiennej socjologicznie rzeczywistości. Opiera się na własnym doświadczeniu - wykładowcy akademickiego zdobytym podczas prac badawczych prowadzonych w Królestwie Arabii Saudyjskiej w latach 
2010-2012. Podejmuje bardzo drażliwe tematy etnograficzne i opisuje trudności jakim musiała sprostać zarówno w procesie zdobywania danych przed rozpoczęciem badań, w czasie ich trwania, ale także po ich zakończeniu. W niezwykle interesujacy sposób przedstawia dylematy wynikajace $\mathrm{z}$ „bycia” w nieznanej kulturze. Mamy także możliwość współuczestniczenia w małych zwycięstwach autorki osiaganych podczas zdobywania fachowej wiedzy. W swojej publikacji Odrową̇-Coates podejmuje również temat wpływu doświadczeń terenowych na osobę badacza i „leczących” właściwości analizy danych zebranych po przeprowadzeniu badań.

W eseju "If I were Chechen, I would be a feminist..." Agnieszki Gutkowskej poznajemy refleksje autorki na temat jej pracy z imigrantami i uchodźcami z Czeczeni, gdy jako pełnomocnik działający w ich imieniu zmagała się z procedurami ubiegania się o status uchodźcy. Autorka dzieli się swoimi doświadczeniami z kilkunastu lat pracy poświęconych szeroko rozumianym tematom migracji i wielokulturowości. Występuje przy tym zarówno z pozycji obserwatora jak i uczestnika. Co jak pisze, niesie to ze sobą ryzyko utraty zawodowego dystansu do pracy. Podkreśla, że wiedza o kulturze Czeczenów, ich wartościach i normach, która uzyskała, „będąc z nimi”, nigdy nie byłaby dla niej dostępna gdyby zajmowała się tematem z czysto teoretycznego punktu widzenia. Doświadczenie to wykorzystała później w badaniach naukowych, które koncentrowały się na sytuacjach konfliktu norm i granic kompromisu wśród badanej społeczności. Interesujące wydaje się zwłaszcza zderzenie kultury europejskiej, w której się wychowała i kultury muzułmańskiej w sposobie rozumienia roli kobiety w rodzinie, życiu społeczności, świecie.

W rozdziale „A Scattered Mosaic of Records and Reminiscences”: Ženi Lebl's War Odyssey in Her Personal Writings" Katarzyna Tarczyńska przeprowadza dokładną analizę prozy autobiograficznej serbskiej badaczki i pisarki, Ženi Lebl, której tragiczne życiowe doświadczenia nie odebrały witalności i energii, ale były wręcz powodem dla którego chciała dzielić się nimi ze światem i pozostawiać świadectwo o II wojnie światowej. Pragnęła pokazać, że w obozach dla więźniów m.in. Goli Otok byli nie tylko ludzie, ale były także kobiety, których przeżycia były często marginalizowane. Wspomnienia Lebl są zapisem jej osobistej historii umieszczonej w kontekście historii tamtych lat niesłychanie emocjonujacym i przejmujacym.

Agnieszka Wołowicz - Ruszkowska w swoim artykule „A study of women with disabilities - the emancipatory perspective" zwraca uwage na to, że zjawiska społeczne rzadko są łatwe w odczytaniu i badaniu, gdyż angażuje się je zarówno w oparciu o kryteria stworzone przez samego badacza jak i te stworzone przez normy i tradycje danej społeczności. Autorka uważa temat wykluczenia kobiet $\mathrm{z}$ niepełnosprawnością intelektualną za szczególnie ważny, dochodzi bowiem do dyskryminacji podwójnej, ze względu na płeć i niepełnosprawność. Zarówno od strony prawnej (obowiązujących przepisów, które usuwają płeć i zwracają uwagę na brak zdolność) jak i społecznej, jako akceptacja bezpłciowego wizerunku kobiet niepełnosprawnych intelektualnie. Autorka opisuje próby poszukiwania strategii badań, która mogłaby obejmować obie kategorie zarówno płeć jak i niepełnosprawność.

W rozdziale zatytułowanym „The dilemmas and passions in intercultural field research - a female pedagogue's ethnographic notes” Urszuli Markowskiej - 
Manista, poznajemy teoretyczne i praktyczne aspekty badań terenowych prowadzonych przez kobiety. Autorka odnosi się do swoich doświadczeń zdobytych podczas pracy w Republice Środkowej Afryki, Rogu Afryki i na południowym Kaukazie mówiąc nie tylko o plusach, ale także o trudach pracy w kulturowo obcej rzeczywistości. Podkreśla, że każde badanie jest konfrontacją z niezliczoną ilościa relacji i nieprzewidywalnych scenariuszy. Jej rozważania prowadzą do postawienia pytań o granice miedzy praca akademicka, a życiem prywatnym. Umieszcza temat kobiet $\mathrm{w}$ badaniach terenowych $\mathrm{w}$ kategoriach pomiędzy pasją badawcza, a licznymi dylematami, związanymi z byciem kobieta - badaczem w odległych miejscach, w społecznościach bardzo zróżnicowanych pod względem kultury i struktury społecznej.

W artykule Justyny Pilarskiej „Culturally sensitive research - on theory and some good examples" znajdziemy przegląd podejść metodologicznych stosowanych $\mathrm{w}$ badaniach prowadzonych w środowiskach odmiennych kulturowo. Autorka podkreśla, że wrażliwość kulturowa badacza jest warunkiem wstępnym do podejmowania tego typu badań. Wskazuje też tematy, które należy brać pod uwage w badaniach międzykulturowych. Justyna Pilarska zwraca uwagę, że należy w ocenie pracy pozostawić miejsce na specyficzne niuanse danej społeczności przy jednoczesnym akceptowaniu dużej różnorodności kulturowej. W artykule mamy także możliwość poznania przykładów najlepszych praktyk badawczych, które omówione są na podstawie różnych projektów.

Pomimo, że teksty są oddzielnymi publikacjami, to wszystkie one tworzą swego rodzaju przewodnik po doświadczeniach i wyzwaniach czekających na kobiety, które podejmują się badań w terenie. Skłaniają nas również do refleksji na temat miejsca kobiety w nauce, szczególnie w dziedzinie badań międzykulturowych. 